The Female Circumcision Controversy 
This page intentionally left blank 


\section{The Female Circumcision Controversy}

An Anthropological Perspective

Ellen Gruenbaum

\section{$\overline{\text { PENN }}$}

University of Pennsylvania Press

Philadelphia 
Copyright $(9) 2001$ Ellen Gruenbaum

All rights reserved

Printed in the United States of America on acid-free paper

10987654

Published by

University of Pennsylvania Press

Philadelphia, Pennsylvania 19104-4011

Library of Congress Cataloging-in-Publication Data

Gruenbaum, Ellen.

The female circumcision controversy : an anthropological perspective / Ellen Gruenbaum.

p. $\mathrm{cm}$.

Includes bibliographical references and index.

ISBN 0-8122-3573-8 (cloth : alk. paper) - ISBN 0-8122-1746-2 (pbk. : alk. paper)

1. Female circumcision. I. Title.

GN484 .G78 2000

$392.1-\mathrm{dc} 21$

00-041803 
For my parents,

Ruth and Luther Gruenbaum 
This page intentionally left blank 